recipients. N Engl J Med. 2008;358:811-7. http://dx.doi.org/10.1056/ NEJMoa0706992

4. Debing Y, Moradpour D, Neyts J, Gouttenoire J. Update on hepatitis E virology: implications for clinical practice. J Hepatol. 2016;65:200-12. http://dx.doi.org/10.1016/j.jhep.2016.02.045

5. Woo PC, Lau SK, Teng JL, Tsang AK, Joseph M, Wong EY, et al. New hepatitis E virus genotype in camels, the Middle East. Emerg Infect Dis. 2014;20:1044-8. http://dx.doi.org/10.3201/ eid2006.140140

6. Lee GH, Tan BH, Teo EC, Lim SG, Dan YY, Wee A, et al. Chronic infection with camelid hepatitis $\mathrm{E}$ virus in a liver transplant recipient who regularly consumes camel meat and milk. Gastroenterology. 2016;150:355-7.e3. http://dx.doi.org/10.1053/j. gastro.2015.10.048

7. Woo PC, Lau SK, Lam CS, Tsang AK, Hui SW, Fan RY, et al. Discovery of a novel bottlenose dolphin coronavirus reveals a distinct species of marine mammal coronavirus in Gammacoronavirus. J Virol. 2014;88:1318-31. http://dx.doi.org/10.1128/JVI.02351-13

8. Smith DB, Purdy MA, Simmonds P. Genetic variability and the classification of hepatitis E virus. J Virol. 2013;87:4161-9. http://dx.doi.org/10.1128/JVI.02762-12

9. Kumar S, Stecher G, Tamura K. MEGA7: Molecular Evolutionary Genetics Analysis version 7.0 for bigger datasets. Mol Biol Evol. 2016;33:1870-4. http://dx.doi.org/10.1093/molbev/msw054

10. Abro AH, Abdou AM, Saleh AA, Ustadi AM, Hussaini HS. Hepatitis E: a common cause of acute viral hepatitis. J Pak Med Assoc. 2009;59:92-4.

Address for correspondence: Patrick C.Y. Woo, State Key Laboratory of Emerging Infectious Diseases, Department of Microbiology, The University of Hong Kong, University Pathology Building, Queen Mary Hospital, Hong Kong; email: pcywoo@hku.hk; Kwok-Yung Yuen, State Key Laboratory of Emerging Infectious Diseases, Department of Microbiology, The University of Hong Kong, University Pathology Bldg., Queen Mary Hospital, Hong Kong; email: kyyuen@hku.hk

\section{Avian Influenza Virus H5 Strain with North American and Eurasian Lineage Genes in an Antarctic Penguin}

\author{
Gonzalo P. Barriga, Dusan Boric-Bargetto, \\ Marcelo Cortez-San Martin, Víctor Neira, \\ Harm van Bakel, Michele Thompsom, \\ Rodrigo Tapia, Daniela Toro-Ascuy, \\ Lucila Moreno, Yesseny Vasquez, \\ Michel Sallaberry, Fernando Torres-Pérez, \\ Daniel González-Acuña, Rafael A. Medina
}

Author affiliations: Pontificia Universidad Católica de Chile, Santiago, Chile (G.P. Barriga, R.A. Medina); Pontificia Universidad Católica de Valparaíso, Valparaíso, Chile (D. Boric-Bargetto,

F. Torres-Pérez); Universidad de Santiago, Santiago
(M. Cortez-San Martin, D. Toro-Ascuy, Y. Vasquez); Universidad de Chile, Santiago (V. Neira, R. Tapia, M. Sallaberry); Icahn School of Medicine at Mount Sinai, New York, New York, USA (H. van Bakel, R.A. Medina); Universidad de Concepción, Concepción, Chile (M. Thompsom, L. Moreno, D. González-Acuña); Millennium Institute on Immunology and Immunotherapy, Santiago (R.A. Medina)

DOI: http://dx.doi.org/10.3201/eid2212.161076

To the Editor: Previous studies have reported avian influenza virus (AIV)-positive serum samples obtained from Adélie (Pygoscelis adeliae), chinstrap (Pygoscelis antarcticus), and gentoo (Pygoscelis papua) penguins (1-4). Only recently was an H11N2 subtype virus isolated from Adélie penguins in Antarctica (5). We performed AIV surveillance in the Antarctic Peninsula to identify the strains currently circulating in different penguins species in this area.

During 2015-2016, we sampled penguin colonies from 9 locations on the Antarctic Peninsula. We collected 138 blood samples from Adélie penguins at Ardley Island $\left(62^{\circ} 13^{\prime} \mathrm{S}, 58^{\circ} 56^{\prime} \mathrm{W}\right)$, Arctowski Base $\left(62^{\circ} 9^{\prime} \mathrm{S}, 58^{\circ} 28^{\prime} \mathrm{W}\right)$, and Bernardo O'Higgins Base $\left(63^{\circ} 19^{\prime} \mathrm{S}, 57^{\circ} 53^{\prime} \mathrm{W}\right)$ and identified 5 serum samples positive for influenza. We also collected 513 cloacal swabs from Adélie, chinstrap (online Technical Appendix Figure 1, panel A; http://wwwnc.cdc. gov/EID/article/22/12/16-1076-Techapp1.pdf), and gentoo penguins from Mikkelsen Harbor $\left(63^{\circ} 54^{\prime} \mathrm{S}, 60^{\circ} 47^{\prime} \mathrm{W}\right)$, Dorian Bay and Port Lockroy $\left(64^{\circ} 48^{\prime} \mathrm{S}, 63^{\circ} 30^{\prime} \mathrm{W}\right)$, Pleneau Island $\left(65^{\circ} 06^{\prime} \mathrm{S}, 64^{\circ} 04^{\prime} \mathrm{W}\right)$, Brown Base $\left(64^{\circ} 53^{\prime} \mathrm{S}\right.$, $\left.62^{\circ} 52^{\prime} \mathrm{W}\right)$, Orne Harbor $\left(64^{\circ} 37^{\prime} \mathrm{S}, 62^{\circ} 32^{\prime} \mathrm{W}\right)$, and Aitcho Island $\left(62^{\circ} 23^{\prime} \mathrm{S}, 59^{\circ} 46^{\prime} \mathrm{W}\right)$ during January-March of 2 consecutive seasons (2015 and 2016; online Technical Appendix Figure 1, panel B; http://wwwnc.cdc.gov/EID/ article/22/12/16-1076-Techapp1.pdf). Quantitative reverse transcription PCR (RT-PCR) analysis of the matrix segment (6) identified 21 positive AIV samples from penguins (8 chinstrap, 13 gentoo) on Aitcho Island, demonstrating the presence of AIV in 2 additional penguin species in a new location in Antarctica.

Using multisegment RT-PCR performed with influenza-specific universal primers, we amplified all 8 virus segments from a chinstrap penguin specimen, which yielded cDNA products suitable for next-generation sequencing with a HiSeq 2500 System (Illumina, San Diego, CA, USA). This virus was subtyped as an $\mathrm{H} 5 \mathrm{~N} 5$ and named $\mathrm{A} /$ chinstrap_penguin/Antarctica/B04/2015 (H5N5). Analysis of its cleavage site confirmed this was a typical low pathogenicity AIV (LPAIV) containing cleavage motif PQRETRGLF (7).

To trace the origin of this H5N5 virus, we performed phylogenetic analyses of its hemagglutinin and neuraminidase genes (Figure, panels A, B; online Technical Appendix Figures 2, 3, http://wwwnc.cdc.gov/EID/article/22/12/161076-Techapp1.pdf). The hemagglutinin gene was placed 

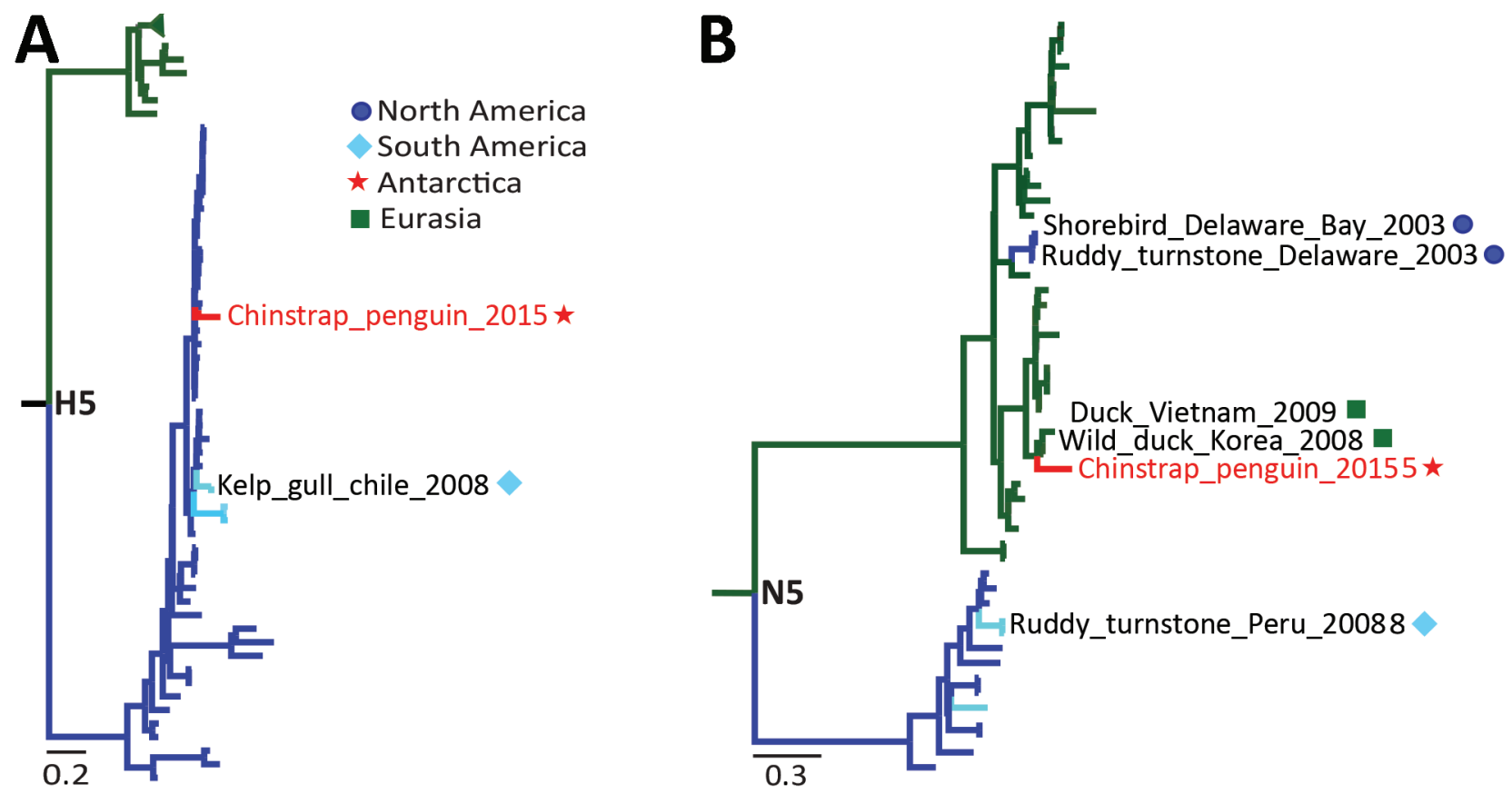

Figure. Low pathogenicity avian influenza virus (AIV) (H5N5) found in Antarctic penguin. A) Phylogenetic analysis of the HA gene showing its relationship to $\mathrm{H} 5$ low pathogenicity North American lineage viruses. B) Phylogenic analysis of the NA gene showing its relationship to N5 viruses from Eurasia. Antarctic strains: red lines, stars; Eurasian strains: green lines, squares; North American strains: dark blue lines, circles; South American strains: light blue lines, diamonds. Sequences were selected from public databases to cover a wide diversity of AIV strains from different years and geographic locations and aligned with MUSCLE (http://www.drive5.com/muscle/). The maximum-likelihood trees of $325 \mathrm{HA}$ and 319 NA nucleotide sequences were constructed with MEGA6 (http://www.megasoftware.net) and IQ-TREE on the IQTREE web server (http://www.cibiv.at/software/iqtree/) by using the maximum-likelihood method with 1,000 ultrafast bootstrap replicates. Summarized trees are shown for the $\mathrm{H} 5$ and N5 clusters. Further details are provided in online Technical Appendix Figures 2, 3 (http:// wwwnc.cdc.gov/EID/article/22/12/16-1076-Techapp1.pdf). The best-fit model of substitution was found by using the auto function on the IQ-TREE web server and Akaike information criterion. Scale bars indicate nucleotide substitutions per site. AIV, avian influenza virus; HA, hemagglutinin; NA, neuraminidase.

into a clade within the H5 American LPAIV lineage, clustering with AIVs isolated from ducks in the United States during 2007-2014 and blue-winged teals from Guatemala in 2010 (online Technical Appendix Figure 2). This finding suggests a possible introduction of this H5 AIV into Antarctica via the Pacific or the Mississippi-American flyways, although we cannot rule out that this H5 strain is endemic to other South America locations.

The timing of arrival of migratory birds that breed in Antarctica (e.g., skua, shags, petrel, and gulls) overlaps with that of the penguins as they return to colonies for breeding and nesting during the summer in the Southern Hemisphere. These birds share a habitat, enabling close contact $(5,8)$ and introducing the possibility of AIV spillover from flying birds to penguins. The chinstrap penguin H5 strain also clustered near the H5 strain isolated in 2008 from a kelp gull (Larus dominicanus) in Chile (9), indicating a potential route of transmission and introduction of AIV into Antarctic penguins (Figure, panel A). Kelp gull colonies are found in the Antarctic, the sub-Antarctic territory, and along the coastline of Chile and Argentina.
Hence, gulls and other intermediate vector hosts, such as the south polar skua (Stercorarius maccormicki), might represent natural reservoirs that play a role in the introduction and maintenance of AIVs into Antarctica.

The chinstrap penguin neuraminidase segment clustered within a Eurasian N5 clade that includes sequences from 2001-2010 (Figure, panel B; online Technical Appendix Figure 3). The closest sequences were isolated from wild ducks from South Korea in 2008 (GenBank accession no. JX679163) and Vietnam in 2009 (GenBank accession no. AB593481). Eurasian N5s have sporadically been found in ruddy turnstones (Arenaria interpres) and an unidentified shore bird at Delaware Bay (GenBank accession nos. CY144466.1, CY144458.1, and CY102738.1). This finding suggests a plausible entryway of this gene into Antarctica from South America through the Atlantic or PacificAmerican flyway, which are common routes used by shore birds, such as the ruddy turnstone, white-rumped sandpiper (Calidris fuscicollis), and red knot (Calidris canutus) (10).

As previously suggested for H11N2 viruses from Antarctica, our data supports the idea that these AIVs are 
evolutionarily distinct from other AIVs (5). This H5N5 strain is a contemporary reassortant virus related to North American and Eurasian strains.

The positive animals we identified originated from a single location on the Antarctic Peninsula, which suggests recent introduction of this AIV H5N5 in the colonies sampled. Antarctica is refuge for most penguin colonies, including the near-threatened emperor penguins. Previous reports suggested that AIV could have caused Adélie penguin chick death (3). Four positive samples (including the sequenced virus) were obtained from juvenile chinstrap penguins that were weak, depressed, and possibly ill (i.e., they had ruffled feathers, lethargy, and impaired movement). Thus, additional studies are warranted to assess the health and conservation status of resident bird species and potential pathologic effects of AIV.

These data provide novel insights on the ecology of AIV in Antarctica. Our findings also highlight the need for increased surveillance to understand virus diversity on this continent and its potential contribution to the genetic constellation of AIV in the Americas.

\section{Acknowledgments}

We are grateful to K. Tapia, who was an excellent and invaluable technical assistance during the course of this study. We also thank the Instituto Antartico Chileno (INACH) staff for all their support during the expeditions to Antarctica.

This study was partly funded by the Center for Research in Influenza Pathogenesis (CRIP), a National Institute of Allergy and Infectious Diseases-funded Center of Excellence in Influenza Research and Surveillance (CEIRS), contract number HHSN272201400008C to R.A.M., and by the Programa de Investigación Asociativa from the Comisión Nacional de Investigación Científica y Tecnológica, project CONICYT-PIA Anillo1408 to R.A.M., F.T.P., and V.N. D.G.-A. is supported by grant RT_12-13, and M.C.-S.M. is supported by the grant RT_08-13, both awarded from INACH. G.P.B is supported by the Fondo Nacional de Desarrollo Científica y Techológica (FONDECYT) de Postdoctorado 3150564 from CONICYT, and D. B.-B. is supported by Vicerrectoría de Investigación y Estudios Avanzados-Pontificia Universidad Católica de Valparaíso.

\section{References}

1. Austin FJ, Webster RG. Evidence of ortho- and paramyxoviruses in fauna from Antarctica. J Wildl Dis. 1993;29:568-71. http://dx.doi.org/10.7589/0090-3558-29.4.568

2. Baumeister E, Leotta G, Pontoriero A, Campos A, Montalti D, Vigo G, et al. Serological evidences of influenza A virus infection in Antarctica migratory birds. Int Congr Ser. 2004;1263:737-40. http://dx.doi.org/10.1016/j.ics.2004.02.099

3. Morgan IR, Westbury HA. Virological studies of Adelie penguins (Pygoscelis adeliae) in Antarctica. Avian Dis. 1981;25:1019-26. http://dx.doi.org/10.2307/1590077

4. Wallensten A, Munster VJ, Osterhaus AD, Waldenstr J, Bonnedahl J, Broman T, et al. Mounting evidence for the presence of influenza A virus in the avifauna of the Antarctic region. Antarct Sci. 2006;18:353-6. http://dx.doi.org/10.1017/ S095410200600040X

5. Hurt AC, Vijaykrishna D, Butler J, Baas C, Maurer-Stroh S, Silva-de-la-Fuente MC, et al. Detection of evolutionarily distinct avian influenza A viruses in Antarctica. MBio. 2014;5:e1098-14. http://dx.doi.org/10.1128/mBio.01098-14

6. Spackman E, Senne DA, Myers TJ, Bulaga LL, Garber LP, Perdue ML, et al. Development of a real-time reverse transcriptase PCR assay for type A influenza virus and the avian $\mathrm{H} 5$ and $\mathrm{H} 7$ hemagglutinin subtypes. J Clin Microbiol. 2002;40:3256-60. http://dx.doi.org/10.1128/JCM.40.9.3256-3260.2002

7. Senne DA, Panigrahy B, Kawaoka Y, Pearson JE, Süss J, Lipkind M, et al. Survey of the hemagglutinin (HA) cleavage site sequence of $\mathrm{H} 5$ and $\mathrm{H} 7$ avian influenza viruses: amino acid sequence at the HA cleavage site as a marker of pathogenicity potential. Avian Dis. 1996;40:425-37. http://dx.doi.org/10.2307/1592241

8. Fretwell PT, Trathan PN. Penguins from space: faecal stains reveal the location of emperor penguin colonies. Global Ecology and Biogeography. 2009 [cited 2016 Sep 8]. http://onlinelibrary.wiley. $\mathrm{com} / \mathrm{doi} / 10.1111 / \mathrm{j} .1466-8238.2009 .00467 . \mathrm{x} / \mathrm{abstract}$

9. Mathieu C, Moreno V, Pedersen J, Jeria J, Agredo M, Gutiérrez C, et al. Avian influenza in wild birds from Chile, 2007-2009. Virus Res. 2015;199:42-5. http://dx.doi.org/10.1016/j.virusres.2015.01.008

10. Krauss S, Stallknecht DE, Negovetich NJ, Niles LJ, Webby RJ, Webster RG. Coincident ruddy turnstone migration and horseshoe crab spawning creates an ecological 'hot spot' for influenza viruses. Proc Biol Sci. 2010;277:3373-9. http://dx.doi.org/10.1098/rspb.2010.1090

Address for correspondence: Rafael A. Medina, Department of Pediatric Infectious Diseases and Immunology, Escuela de Medicina, Pontificia Universidad Católica de Chile, Marcoleta 391, Santiago, Chile; email: rmedinas@med.puc.cl

\section{Pathogenic Lineage of mor-Negative Colistin- Resistant Escherichia coli, Japan, 2008-2015}

\section{Toyotaka Sato, Akira Fukuda, Yuuki Suzuki, Tsukasa Shiraishi, Hiroyuki Honda, Masaaki Shinagawa, Soh Yamamoto, Noriko Ogasawara, Masaru Usui, Hiroki Takahashi, Satoshi Takahashi, Yutaka Tamura, Shin-ichi Yokota}

Author affiliations: Sapporo Medical University School of Medicine, Sapporo, Japan (T. Sato, Y. Suzuki, T. Shiraishi, H. Honda, S. Yamamoto, N. Ogasawara, H. Takahashi, S. Takahashi, S. Yokota); Rakuno Gakuen University, Ebetsu, Japan (A. Fukuda, M. Usui, Y. Tamura); Sapporo Medical University Hospital, Sapporo (M. Shinagawa)

DOI: http://dx.doi.org/10.3201/eid2212.161117 